\title{
Wastewater Treatment Plants as a Source of Bioaerosols
}

\author{
Michał Michałkiewicz* \\ Poznan University of Technology, Institute of Environmental Engineering, Poznań, Poland
}

Received: 28 December 2017

Accepted: 19 April 2018

\begin{abstract}
This study presents the results of bioaerosol analyses conducted in the area of 9 wastewater treatment plants (WTTPs) in the Wielkopolska Region (Poland) with different capacities (from 500 to $\left.200,000 \mathrm{~m}^{3} / \mathrm{day}\right)$. The abundance of mesophilic and psychrophilic bacteria, Staphylococcus, Actinobacteria, Pseudomonas fluorescens, coliform bacteria, and microscopic fungi in different plant sites and the control site were analysed. Microscopic fungi exhibited the highest contribution to air contamination and their highest median value was found in WWTP No. 5, which reached 6,700 colony forming units $\left(\mathrm{CFU} / \mathrm{m}^{3}\right)$ of air. Psychrophiles and mesophiles were the most abundant bacterial groups. It was established that the highest concentration of bioaerosols was observed during the mechanical treatment of wastewater at sewage sludge treatment sites and near bioreactors. The $\mathrm{R}_{a v}$ parameter, which represents the ratio of average annual microbial abundance in the air to the average annual microbial abundance in the background at the control site, was a very good indicator of air contamination rate. This parameter may be analysed with respect to bacteria $\left(\mathrm{R}_{a v}{ }_{B}\right.$, microscopic fungi $\left(\mathrm{R}_{a v}\right)$, and all microorganisms $\left(\mathrm{R}_{a v M}\right)$.
\end{abstract}

Keywords: bioaerosols, emission, sewage, wastewater treatment plants (WWTPs)

\section{Introduction}

Wastewater treatment plants (WWTPs) are objects that may sometimes exhibit a notably negative influence on the environment, including humans, animals, and plants $[1,2]$. The scientific reports regarding the influence of such municipal objects on the nearby environment (water, soil, air) and on humans (workers and inhabitants of nearby areas) have been published both worldwide and in Poland [3-5]. The WWTPs are considered as a source of hazard for human health,

*e-mail: Michal.Michalkiewicz@put.poznan.pl and its scale mainly depends on the amount and characteristics of wastewater, method of treatment, operation rate of WWTPs, the method of sewage sludge treatment, and the type of apparatuses used, as well as meteorological, climatic, and terrain conditions [6, 7]. All the municipal WWTPs are a source of numerous inconveniences for humans and the environment, and their character and range of impact depends on the size of the object, the employed technologies, and operation, as well as the type and number of microorganisms present in wastewater [8-10]. The inconveniences associated with the functioning of WWTPs include:

- Bioaerosols, which comprise microorganisms present in wastewater and that are emitted to the atmosphere at different stages of wastewater treatment. 
- Noise, which is caused by the operation of numerous apparatuses associated with wastewater treatment (e.g., blowers, pumps, centrifuges) and motor vehicles (e.g., transport of wastewater or disposal of screenings and sand).

- Insufficiently treated wastewater that is introduced into groundwater.

- By-products associated with wastewater treatments, e.g., screenings, sludge, sand.

- Unpleasant odours that cause discomfort for the surrounding environment.

- Improper location of the wwtp in the terrain or its close proximity to the residential buildings $[3,7,8]$.

During the wastewater treatment process, numerous microorganisms, toxins, and metabolites are released into the air and form bioaerosols, which are a direct hazard for employees [11]. The bioaerosols gather on ground level and are transported with the wind to nearby areas, thus becoming a source of contamination of plants, animals, and surface waters $[12,13]$. They may also reach the households located in residential areas which are in the immediate or distant neighbourhood of WWTPs $[14,15]$.

Detailed analyses of air at different stages of wastewater treatment in all seasons may be the base for evaluating the influence of a WWTP on the environment and for indicating which apparatuses or processes are the main sources of bioaerosol emissions to the atmosphere. In order to indicate the potential emission sources and evaluate their value, the results of studies regarding bioaerosols from 9 different wastewater treatment plants in Poland were compared within the framework of this article.

\section{Study Area}

Microbial contamination of air was studied on the area of 9 municipal WWTPs which differed in terms of capacity from 500 (No. 5) to $200,000 \mathrm{~m}^{3} /$ day (No. 6). All the analysed objects were mechanicalbiological treatment plants with enhanced biological phosphorous removal. In the majority of WWTPs or in their direct vicinity there were sewage storage points (storage stations) for the supplied sewage. During the mechanical stages of wastewater treatment, the gratings were located both in open and encapsulated (hermetic) buildings (WTTPs Nos. 1, 6, 7, 8, 9), from which the contaminated air was discharged to biofilters. Although the grit separators were mainly open, WWTPs operating with encapsulated (hermetic) grit separators were also present (Nos. 1, 6, 7, 8), from which the air was discharged to biofilters. The separated grit was discharged to a standalone container. The WWTPs included open or encapsulated (Nos. 1, 8) preliminary settling tanks. Biological treatment of wastewater was conducted in bioreactors with the use of activated sludge. The studied WWTPs used the Bardenpho system of biological reactors (No. 7), modified Bardenpho system reactors (Nos. 3, 6), WHL II (No. 2), LANR
II (No. 1), or other bioreactors (Nos. 4, 5, 8, 9) that contained chambers characterized by differing mixing and aeration rates. Some bioreactors were encapsulated (Nos. 1, 8) and the contaminated air was discharged to biofilters. The bioreactor chambers were equipped with low-speed or medium-speed mixers and aeration systems. The nitrification chambers mostly used a fine bubble diffuser pipe, disc and grate systems or Messner's plates, and the air was pumped from the blower station. The purified wastewater effluent from the secondary settling tank was discharged to small watercourses or rivers. In the majority of the studied WWTPs, sludge management was employed and open fermentation chambers (OFC) or closed fermentation chambers (CFC) were present. After stabilisation, the sludge was transported to the sludge management building, where it was subjected to dehydration and hygenisation treatment. Then it was stored in the sludge storage area, sludge fields, lagoons, or subjected to the composting process. In most cases it was periodically exported or used for the reclamation of the WWTP area and served as an organic fertilizer, e.g., for growing of energy willows. On the area of a single WWTP (No. 9) an additional sludge composting site was present. Although the majority of studied WWTPs were located outside residential areas, some of them boarded directly or were in close proximity to individual or collective housing areas. The selection of WWTPs indicated a potential variability in terms of emission sites of microbial contamination in the form of bioaerosols, and simultaneously serve as a representation of the treatment conditions in large and small towns in the Wielkopolska Region as well as in all of Poland.

\section{Materials and Methods}

Taking the possible fluctuation of abundance of microorganisms emitted into the atmosphere in the form of bioaerosols in the annual cycle into account, the microbiological studies conducted in the WWTPs were conducted in all four seasons (spring, summer, fall, winter) during a single year. Several study sites were selected in each WWTP, which were the possible emission sources of bioaerosols. Additionally, the contamination rate of the air was established during so-called background studies, which were usually conducted in an area approx. 150-200 $\mathrm{m}$ away from the WWTP on the windward site. The concentrations were measured outside the WWTPs, without the influence of emitted bioaerosols, during the same day, and with meteorological conditions assumed as background. The following types of microorganisms were analysed during the microbiological assessment of air, in accordance with the Polish Standards: mesophilic bacteria, hemolytic and mannitol-positive and mannitolnegative staphylococci (Staphylococcus), Pseudomonas fluorescens, actinomycetes (Actinobacteria), and microscopic fungi [16, 17]. Currently, there is no 
relevant legislation defining acceptable levels of microbial air contamination in Poland. Previous standards PN-89/Z-04111/02 and PN-89/Z-04111/03, invalidated in 2015 , have not yet been replaced with new documents. Although new PN-EN standards regarding the measurement of microorganisms and endotoxins in air at workstations have been introduced in Poland, these standards do not contain any limit values regarding the admissible amount of microorganisms and endotoxins, which may be used for the evaluation of air purity/ contamination. Taking into account the fact that the studies were conducted in WWPTs in which household wastewater containing gut microflora was the source of bioaerosols, coliform bacteria were also included in the microbial analysis. Additionally, psychrophilic bacteria were also analysed due to the fact that the collection of air samples was conducted in an outdoor environment. The samples were collected at a height of $1.3 \mathrm{~m}$ from the ground using the sedimentation and impaction methods with the MAS 100 Eco type air sampler (Merck). Air temperature $\left({ }^{\circ} \mathrm{C}\right)$, humidity $(\%)$, and wind direction and speed $(\mathrm{m} / \mathrm{s})$ were measured while collecting samples. The types of analysed microorganisms and conditions for their incubation are listed in Table 1.

After the incubation period, the emerged colonies were counted and the final result was given as the colony forming units per $1 \mathrm{~m}^{3}$ of air $\left(\mathrm{CFU} / \mathrm{m}^{3}\right)$. In cases where air samples were collected using the impaction method with the MAS 100 Eco type air sampler, the obtained results were corrected in accordance with the conversion table by Feller. All statistical calculations were carried out using the STASISTICA 10 PL software.

The results of bioaerosol analysis at selected sites in the studied WWTPs allowed for establishing the abundance of specific bacteria and microscopic fungi per $1 \mathrm{~m}^{3}$ of air $\left(\mathrm{CFU} / \mathrm{m}^{3}\right)$, and to evaluate the contamination rate of air by comparing the results obtained at a selected site to those obtained at control sites. This allows for the comparison of the sites on the basis of the so-called $R$ parameter [18], expressed by formula (1), which may be defined as:

$R=\frac{\text { Number of bacteria in the contaminated air }}{\text { Number of bacteria in the ambient air (background study) }}$

Due to the fact that the studied bacteria and microscopic fungi are present in the bioaerosol, their respective detected abundance may be summed up to obtain the average total abundance of all bacteria, fungi, and all microorganisms (bacteria and fungi) for the general evaluation of the studied sites. On the basis of the obtained results, the average abundance of bacteria, average abundance of fungi, and average abundance of all microorganisms (bacteria and microscopic fungi) present at a given research station during the complete analysed period (e.g., during the annual cycle) may be calculated.

The average value was calculated based on equations 2, 3, and 4:

$$
\begin{aligned}
& \text { Average }=\frac{\Sigma B}{n} \\
& \text { Average }=\frac{\Sigma F}{n} \\
& \text { Average }=\frac{\Sigma M}{n}
\end{aligned}
$$

...where:

- $\Sigma B$ - the total amount of all bacteria (mesophilic bacteria, psychrophilic bacteria, Staphylococcus, Actinobacteria, coliform bacteria, Pseudomonas fluorescens) detected in the complete study period at a given research station.

- $\Sigma F-$ the total amount of microscopic fungi detected in the complete study period at a given research station.

Table 1. Types of studied microorganisms and incubation conditions.

\begin{tabular}{|c|c|c|c|}
\hline Microorganisms & Medium & $\begin{array}{c}\text { Incubation temperature } \\
\left({ }^{\circ} \mathrm{C}\right)\end{array}$ & $\begin{array}{c}\text { Incubation time } \\
(\mathrm{h})\end{array}$ \\
\hline Mesophilic bacteria & Nutrient agar & 37 & 48 \\
\hline Psychrophilic bacteria $*$ & Nutrient agar & $20 \pm 2$ & 72 \\
\hline Staphylococcus mannitol-positive and mannitol-negative & Chapman & 37 & 48 \\
\hline Actinobacteria & Pochon & 26 & 120 \\
\hline Coliform bacteria $*$ & Agar Endo & 37 & 48 \\
\hline Pseudomonas fluorescens $* *$ & \multirow{2}{*}{ King B } & 26 & 120 \\
\hline \multirow{2}{*}{ Microscopic fungi } & & 4 & 168 \\
\hline & Waksman & 26 & 168 \\
\cline { 2 - 4 } & Czapek-Dox & 26 & 168 \\
\hline
\end{tabular}

* - not covered by Polish Standards

** - identification of colonies in UV rays 
Table 2. Air contamination rates based on the value of the $R_{a v}$ parameter.

\begin{tabular}{|c|c|}
\hline $\begin{array}{c}R_{a v} \text { parameter } \\
\text { value }\end{array}$ & Air purity class - contamination rate \\
\hline$\leq 5$ & Pure - marginal increase of contamination \\
\hline $6-10$ & $\begin{array}{c}\text { Partially contaminated - notable increase } \\
\text { of contamination }\end{array}$ \\
\hline $11-15$ & $\begin{array}{c}\text { Contaminated - high increase } \\
\text { of contamination }\end{array}$ \\
\hline$\geq 16$ & $\begin{array}{c}\text { Very contaminated - very high increase } \\
\text { of contamination }\end{array}$ \\
\hline
\end{tabular}

- $\Sigma M$ - the total amount of all microorganisms (bacteria and microscopic fungi) detected in the complete study period at a given research station.

- $n$ - amount of samples collected in the annual cycle (usually 4).

This allows for obtaining the average annual results from the control site (windward side) and the remaining sites, which may be potential sources of bioaerosol emission. After the modification of the above-mentioned $R$ parameter, the result may be given in the form of $R$, which represents the ratio of average annual abundance of specific microorganisms in the contaminated air and the average annual abundance of bacteria in the background study, at the control site. Depending on the type of analysed microorganisms, the corresponding parameter is used: $R_{a v B}$ in the case of bacteria (formula 5), $R_{a v F}$ in the case of microscopic fungi (formula 6), and $R_{a v M}$ in the case of all microorganisms (formula 7).

$R_{a v B}=\frac{\text { Annual mean abundance of bacteria in the contaminated air }}{\text { Annual mean abundance of bacteria in the control site (background study) }}$

$R_{a v F}=\frac{\text { Annual mean abundance of fungi in the contaminated air }}{\text { Annual mean abundance of fungi in the control site (background study) }}$

$R_{a v}=\frac{\text { Annual mean abundance of microorganisms in contaminated air }}{\text { Annual mean abundance of microorganisms in the control site (background study) }}$

The calculated $R_{a v}$ values reflect the emission rate of the bioaerosol and the air contamination rate. In order to establish the air purity class, the following modified classification criteria were employed (the modified evaluation according to Kulig [18]), which were presented in Table 2 .

\section{Results and Discussion}

Determining air contamination at the control site during background studies is an important element of microbiological studies, since the result of this measurement is the basis for evaluating the purity/ contamination rate for both the control site as well as the potential sources of emission at the municipal object area. The capacities of the studied WWTPs and the values of the $R_{a v}$ parameter at specific sites of the studied WWTPs are presented in Tables 3 and 4.

The value of the $R_{a v}$ parameter at the site of nine studied WWTPs ranged from 0.5 (pure air) to 241.1 (very contaminated air - very high increase of contamination) and was diverse at times. During the analysis of average annual bacterial abundance, the $R_{a v B}$ ranged from 0.5 to 241.1, in the case of microscopic fungi the $R_{a v F}$ parameter ranged from 0.7 to 101.0, whereas in the case of general microbial abundance, the $R_{a v}$ parameter ranged from 0.7 to 133.6. Due to the different values of the $R_{a v}$ parameter it is beneficial to analyse it separately for bacteria and microscopic fungi as well as for all the microorganisms, since this clearly visualises which microbial group present in the bioaerosol has a decisive influence on the microbial contamination rate of air. The highest increase of air contamination at the WTTP sites in comparison to background studies (control site) were observed in the case of WTTP No. 5, in case of which the abundance of all the studied microbial groups was notably increased at $71 \%$ of the studied sites and a clear strong and very strong increase of air contamination was noted. The smallest increase of air contamination by all microorganisms was observed in WTTPs Nos. 6 and 7 , in case of which only pure of partially contaminated air was found. The highest value of the $R_{a v}$ parameter was noted for WTTP No. 1 (241.1), which indicated a high contamination of air. Taking the wastewater treatment stages into account, it can be noticed that the highest emission of microorganisms and the highest air contamination compared to background studies (control site) occurred during mechanical treatment (WWTPs Nos. 2, 3, 4, 8, 9), sludge management (WWTPs Nos. 2, 4, 5, 9), or biological treatment (WWTP No. 5). Simultaneously, a notable contamination of air inside encapsulated (hermetic) objects was observed (WWTPs Nos. 1,8), which confirms that the encapsulation process is beneficial, as it limits the transfer of microorganisms to the external environment. Comparison of the capacity of specific WWTPs allows for establishing that emission of bioaerosols is not correlated with the amount of treated wastewater.

Kulig [18] reported that the value of the $R$ parameter at a distance of $20 \mathrm{~m}$ from seven Flygt-type pumping stations ranged below 5.0, which indicates pure air, and that the $\mathrm{R}$ value was higher only in a single case reaching 5.2. Other authors usually only report that the background studies were characterized by the lowest contamination [3, 19-22], and, in sporadic cases, that high abundance of microorganisms were present in background studies $[13,23]$. This is associated with the fact that bioaerosols may spread over long distances, which poses a threat not only to workers but also to local residents. The results regarding the samples collected from the air, even outside the WWTP area, indicated that the bioaerosols are present in significant quantities $[13,24,25]$. 
Table 3. Capacity of the WWTP, $R_{a v}$ parameter values for bacteria $\left(R_{a v B}\right)$, microscopic fungi $\left(R_{a v F}\right)$, and all microorganisms $\left(R_{a v M}\right)$ at the specific sites in the studied WWTPs (Nos. 1-4).

\begin{tabular}{|c|c|c|c|c|}
\hline No. station & Location & $R_{a v B}$ & $R_{a v F}$ & $R_{a v M}$ \\
\hline \multicolumn{2}{|r|}{ Wastewater treatment plant No. 1} & \multicolumn{3}{|c|}{ Capacity $9,602-16,000\left(\mathrm{~m}^{3} /\right.$ day $)$} \\
\hline 1 & Screen building (h) & 6.7 & 4.6 & 5.3 \\
\hline 2 & Area next to the screen building & 3.0 & 2.7 & 2.8 \\
\hline 3 & Grit chamber (h) & 12.0 & 8.6 & 9.8 \\
\hline 4 & Area next to the grit chamber & 2.3 & 3.0 & 2.8 \\
\hline 5 & Sludge collection tank (h) & 135.6 & 101.0 & 113.1 \\
\hline 6 & Area next to the sludge collection tank & 2.3 & 4.7 & 3.8 \\
\hline 7 & Primary sedimentation tank (h) & 29.6 & 25.8 & 27.1 \\
\hline 8 & Secondary sedimentation tank & 2.7 & 4.3 & 3.7 \\
\hline 9 & Biological reactor - nitrification chamber N2 (h) & 2.1 & 6.7 & 5.1 \\
\hline 10 & Biological reactor - nitrification chamber N3 & 1.6 & 2.3 & 2.0 \\
\hline 11 & Chamber of separation $\mathrm{K} 4$ & 111.2 & 27.9 & 57.1 \\
\hline 12 & Open drainage tank & 2.1 & 2.0 & 2.0 \\
\hline 13 & Sludge pumping station - chamber K8 & 3.3 & 2.5 & 2.7 \\
\hline 14 & Chamber of separation $\mathrm{K} 9$ & 241.1 & 75.6 & 133.6 \\
\hline 15 & Area between the secondary sedimentation tank 2 and 3 & 2.8 & 4.8 & 4.1 \\
\hline \multicolumn{2}{|r|}{ Wastewater treatment plant No. 2} & \multicolumn{3}{|c|}{ Capacity $2,300\left(\mathrm{~m}^{3} /\right.$ day $)$} \\
\hline 1 & At the grit chamber, next to open unheated standardrate digester & 88.1 & 5.3 & 21.9 \\
\hline 2 & Grit separator & 4.8 & 2.9 & 3.3 \\
\hline 3 & Biological reactor & 3.7 & 1.9 & 2.2 \\
\hline 4 & Secondary sedimentation tank & 3.5 & 2.0 & 2.3 \\
\hline 5 & Island station roof of dray sludge & 5.9 & 2.1 & 2.8 \\
\hline 6 & Conventional sand drying beds & 15.9 & 10.0 & 11.2 \\
\hline 7 & Entry to the treatment plant & 1.7 & 1.6 & 1.6 \\
\hline \multicolumn{2}{|r|}{ Wastewater treatment plant No. 3} & \multicolumn{3}{|c|}{ Capacity $5,883\left(\mathrm{~m}^{3} /\right.$ day $)$} \\
\hline 1 & Station of sewage from septic tank & 5.3 & 2.3 & 3.0 \\
\hline 2 & Grit chamber near bar racks building & 4.9 & 2.7 & 3.3 \\
\hline 3 & Primary sedimentation tank & 16.7 & 5.8 & 8.5 \\
\hline 4 & Biological reactor & 2.3 & 2.4 & 2.3 \\
\hline 5 & Secondary sedimentation tank & 4.8 & 7.4 & 6.7 \\
\hline 6 & Open unheated standard rate digester & 3.5 & 5.9 & 5.3 \\
\hline 7 & Transport of sludge & 6.3 & 4.4 & 4.9 \\
\hline \multicolumn{2}{|r|}{ Wastewater treatment plant No. 4} & \multicolumn{3}{|c|}{ Capacity $1,138\left(\mathrm{~m}^{3} /\right.$ day $)$} \\
\hline 1 & Station of sewage from septic tank & 17.9 & 3.1 & 6.1 \\
\hline 2 & Entry to the treatment plant & 5.1 & 1.2 & 2.0 \\
\hline 3 & Biological reactor & 3.3 & 2.2 & 2.4 \\
\hline 4 & Disinfection and dewatering system & 7.4 & 2.6 & 3.6 \\
\hline 5 & Conventional sand drying beds & 26.6 & 10.1 & 13.4 \\
\hline
\end{tabular}

$\mathrm{h}$ - internally hermetic environment 
Table 4. Capacity of the WWTP, $R_{a v}$ parameter values for bacteria $\left(R_{a v B}\right)$, and microscopic fungi $\left(R_{a v F}\right)$ and all microorganisms $\left(R_{a v M}\right)$ at the specific sites in the studied WWTPs (Nos. 5-9).

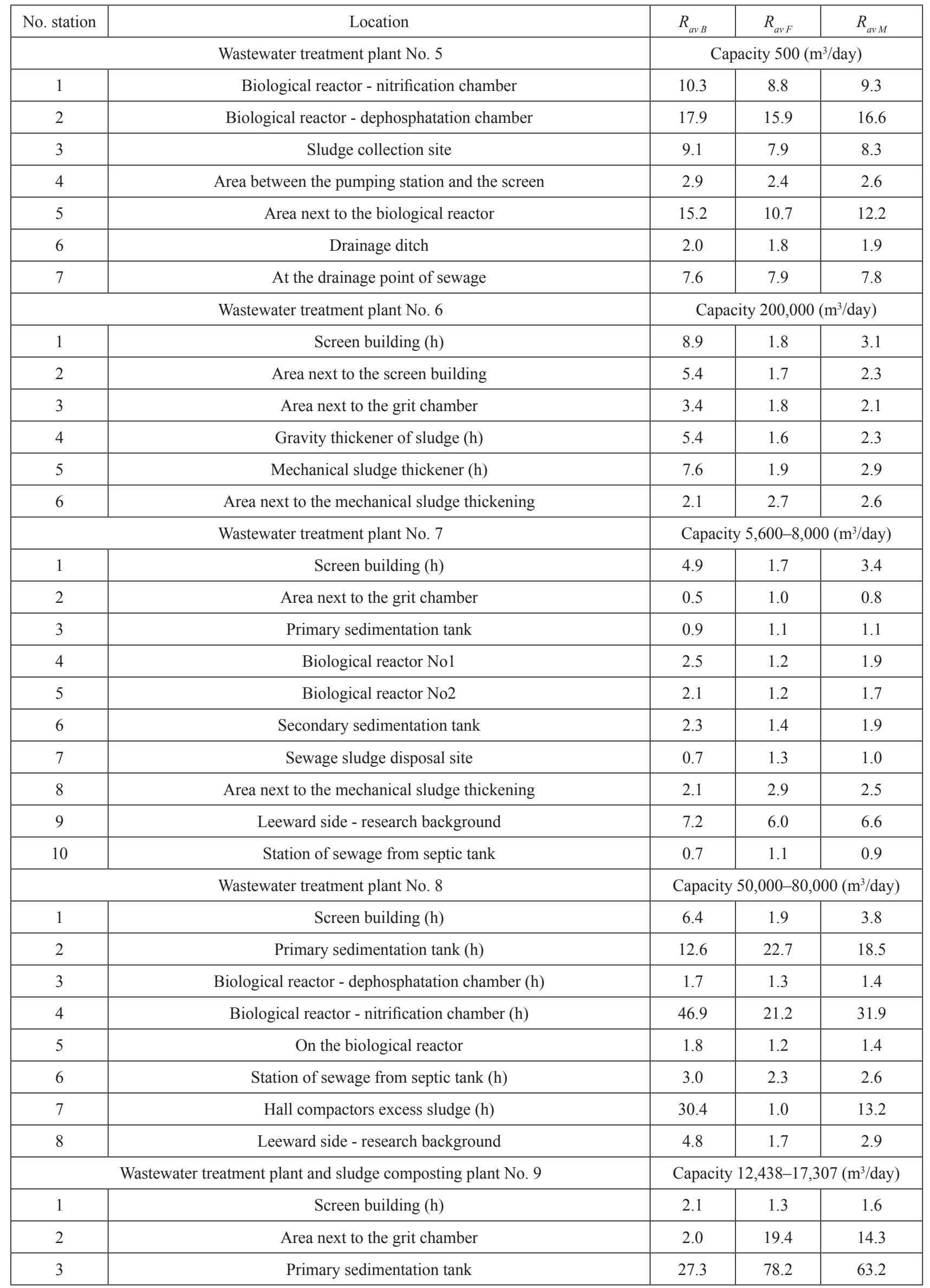


Table 4. Continued.

\begin{tabular}{|c|c|c|c|c|}
\hline 4 & Biological reactor & 1.5 & 5.2 & 4.1 \\
\hline 5 & Area next to the mechanical sludge thickening & 21.6 & 29.7 & 27.3 \\
\hline 6 & Open unheated standard rate digester & 0.8 & 0.7 & 0.7 \\
\hline 7 & Sludge dewatering station & 2.1 & 0.8 & 1.2 \\
\hline 8 & Composting plant - windward side & 0.9 & 0.8 & 0.8 \\
\hline 9 & Composting plant - leeward side & 0.8 & 25.9 & 18.6 \\
\hline
\end{tabular}

$\mathrm{h}$ - internally hermetic environment

Table 5. Average value (Av.), standard deviation (SD), and median values (Med.) of the microorganisms studied $\left(\mathrm{CFU} / \mathrm{m}^{3}\right)$ in research stations in the studied WWTPs (Nos. 1-9).

\begin{tabular}{|c|c|c|c|c|c|c|c|c|c|c|c|}
\hline \multirow[b]{2}{*}{ 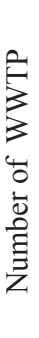 } & \multirow[b]{2}{*}{ 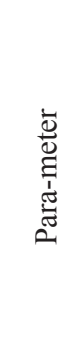 } & \multicolumn{10}{|c|}{ Microorganisms $\left(\mathrm{CFU} / \mathrm{m}^{3}\right)$} \\
\hline & & 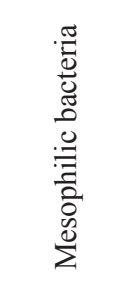 & 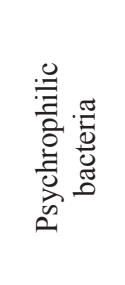 & 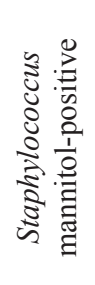 & 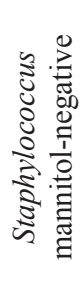 & 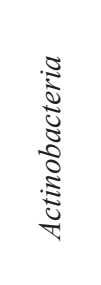 & $\begin{array}{l}\cdot \frac{\pi}{0} \\
0 \\
0 \\
0 \\
0 \\
0 \\
0 \\
0 \\
0\end{array}$ & 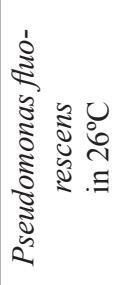 & 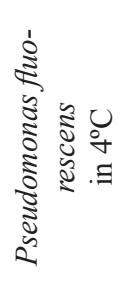 & 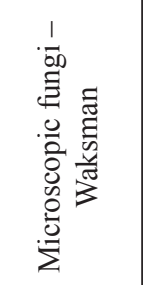 & 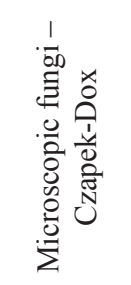 \\
\hline \multirow[t]{2}{*}{1} & $\begin{array}{l}\text { Av. } \\
\text { SD }\end{array}$ & $\begin{array}{c}5,300 \\
\pm 20,845 \\
\end{array}$ & $\begin{array}{c}11,475 \\
\pm 33,465 \\
\end{array}$ & $\begin{array}{c}5 \\
\pm 10 \\
\end{array}$ & $\begin{array}{c}8 \\
\pm 20 \\
\end{array}$ & Ns & $\begin{array}{c}1,054 \\
\pm 7,469 \\
\end{array}$ & $\begin{array}{c}57 \\
\pm 236 \\
\end{array}$ & $\begin{array}{l}0.3 \\
\pm 2 \\
\end{array}$ & $\begin{array}{c}4,935 \\
\pm 14,747 \\
\end{array}$ & $\begin{array}{c}11,475 \\
\pm 33,465 \\
\end{array}$ \\
\hline & Med. & 200 & 1,250 & 0 & 0 & Ns & 0 & 0 & 0 & 1,780 & 1,250 \\
\hline \multirow[t]{2}{*}{2} & $\begin{array}{l}\text { Av. } \\
\text { SD }\end{array}$ & $\begin{array}{c}5,076 \\
\pm 14,937\end{array}$ & $\begin{array}{c}9,619 \\
\pm 20,362\end{array}$ & $\begin{array}{c}150 \\
\pm 176\end{array}$ & $\begin{array}{c}35 \\
\pm 69\end{array}$ & Ns & $\begin{array}{c}3,413 \\
\pm 17,157\end{array}$ & $\begin{array}{c}144 \\
\pm 616\end{array}$ & $\begin{array}{c}3 \\
\pm 16\end{array}$ & $\begin{array}{c}8,422 \\
\pm 15,781\end{array}$ & $\begin{array}{c}5,730 \\
\pm 10,214\end{array}$ \\
\hline & Med. & 590 & 2,280 & 79 & 0 & Ns & 0 & 0 & 0 & 2,125 & 1,610 \\
\hline \multirow[t]{2}{*}{3} & $\begin{array}{l}\text { Av. } \\
\text { SD }\end{array}$ & $\begin{array}{c}1,865 \\
\pm 3,325\end{array}$ & $\begin{array}{c}4,365 \\
\pm 3,596\end{array}$ & $\begin{array}{c}25 \\
\pm 38\end{array}$ & $\begin{array}{c}27 \\
\pm 41\end{array}$ & Ns & $\begin{array}{c}144 \\
\pm 585\end{array}$ & $\begin{array}{c}7 \\
\pm 26\end{array}$ & $\begin{array}{c}0 \\
\pm 0\end{array}$ & $\begin{array}{c}7,590 \\
\pm 10,911\end{array}$ & $\begin{array}{c}5,034 \\
\pm 4,371\end{array}$ \\
\hline & Med. & 790 & 3,615 & 0 & 0 & Ns & 0 & 0 & 0 & 4,440 & 4,325 \\
\hline \multirow[t]{2}{*}{4} & $\begin{array}{l}\text { Av. } \\
\text { SD }\end{array}$ & $\begin{array}{r}1,988 \\
\pm 2,591 \\
\end{array}$ & $\begin{array}{r}7,652 \\
\pm 9,131 \\
\end{array}$ & $\begin{array}{r}35 \\
\pm 36 \\
\end{array}$ & $\begin{array}{c}26 \\
\pm 33 \\
\end{array}$ & Ns & $\begin{array}{c}75 \\
\pm 176 \\
\end{array}$ & $\begin{array}{c}83 \\
\pm 276 \\
\end{array}$ & $\begin{array}{c}0 \\
\pm 0 \\
\end{array}$ & $\begin{array}{c}6,723 \\
\pm 10,753 \\
\end{array}$ & $\begin{array}{c}5,862 \\
\pm 8,681 \\
\end{array}$ \\
\hline & Med. & 1,180 & 4,800 & 26 & 0 & Ns & 0 & 0 & 0 & 2,830 & 2,280 \\
\hline \multirow[t]{2}{*}{5} & $\begin{array}{l}\text { Av. } \\
\text { SD }\end{array}$ & $\begin{array}{c}3,851 \\
\pm 4,880 \\
\end{array}$ & $\begin{array}{c}7,900 \\
\pm 8,945 \\
\end{array}$ & $\begin{array}{c}131 \\
\pm 284 \\
\end{array}$ & $\begin{array}{c}44 \\
\pm 74 \\
\end{array}$ & Ns & $\begin{array}{c}241 \\
\pm 754 \\
\end{array}$ & $\begin{array}{c}12 \\
\pm 20 \\
\end{array}$ & $\begin{array}{c}0 \\
\pm 0 \\
\end{array}$ & $\begin{array}{c}7,054 \\
\pm 7,817 \\
\end{array}$ & $\begin{array}{c}13,430 \\
\pm 15,047 \\
\end{array}$ \\
\hline & Med. & 1,300 & 3,700 & 26 & 0 & Ns & 26 & 0 & 0 & 3,900 & 6,700 \\
\hline \multirow[t]{2}{*}{6} & $\begin{array}{l}\text { Av. } \\
\text { SD }\end{array}$ & $\begin{array}{c}583 \\
\pm 735 \\
\end{array}$ & $\begin{array}{c}1,898 \\
\pm 2,221 \\
\end{array}$ & $\begin{array}{c}20 \\
\pm 24 \\
\end{array}$ & $\begin{array}{c}17 \\
\pm 37 \\
\end{array}$ & $\begin{array}{c}110 \\
\pm 106 \\
\end{array}$ & $\begin{array}{c}44 \\
\pm 106 \\
\end{array}$ & $\begin{array}{c}3 \\
\pm 6 \\
\end{array}$ & $\begin{array}{c}0 \\
\pm 0 \\
\end{array}$ & $\begin{array}{c}2,198 \\
\pm 1,875\end{array}$ & $\begin{array}{c}2,018 \\
\pm 2,629 \\
\end{array}$ \\
\hline & Med. & 360 & 760 & 10 & 0 & 80 & 10 & 0 & 0 & 1,300 & 1,010 \\
\hline \multirow[t]{2}{*}{7} & $\begin{array}{l}\text { Av. } \\
\text { SD }\end{array}$ & $\begin{array}{c}894 \\
\pm 1,927 \\
\end{array}$ & $\begin{array}{c}3,126 \\
\pm 7,933 \\
\end{array}$ & $\begin{array}{c}29 \\
\pm 38 \\
\end{array}$ & $\begin{array}{c}8 \\
\pm 13 \\
\end{array}$ & $\begin{array}{c}686 \\
\pm 1,327 \\
\end{array}$ & $\begin{array}{c}7 \\
\pm 19 \\
\end{array}$ & $\begin{array}{c}6 \\
\pm 20 \\
\end{array}$ & $\begin{array}{c}0 \\
\pm 0 \\
\end{array}$ & $\begin{array}{c}2,098 \\
\pm 4,146 \\
\end{array}$ & $\begin{array}{c}1,319 \\
\pm 2,232 \\
\end{array}$ \\
\hline & Med. & 160 & 820 & 20 & 0 & 75 & 0 & 0 & 0 & 1,120 & 740 \\
\hline \multirow[t]{2}{*}{8} & $\begin{array}{l}\text { Av. } \\
\text { SD }\end{array}$ & $\begin{array}{c}6,539 \\
\pm 17,449 \\
\end{array}$ & $\begin{array}{c}3,730 \\
\pm 10,239 \\
\end{array}$ & $\begin{array}{c}9 \\
\pm 13 \\
\end{array}$ & $\begin{array}{c}56 \\
\pm 176 \\
\end{array}$ & $\begin{array}{c}48 \\
\pm 81 \\
\end{array}$ & $\begin{array}{c}609 \\
\pm 1,654 \\
\end{array}$ & $\begin{array}{c}33 \\
\pm 88 \\
\end{array}$ & $\begin{array}{c}0 \\
\pm 0\end{array}$ & $\begin{array}{c}1,105 \\
\pm 1,450 \\
\end{array}$ & $\begin{array}{c}7,035 \\
\pm 21,428 \\
\end{array}$ \\
\hline & Med. & 670 & 1,180 & 0 & 0 & 10 & 5 & 0 & 0 & 740 & 840 \\
\hline \multirow[t]{2}{*}{9} & $\begin{array}{l}\text { Av. } \\
\text { SD }\end{array}$ & $\begin{array}{c}464 \\
\pm 704\end{array}$ & $\begin{array}{c}18,465 \\
\pm 62,778\end{array}$ & $\begin{array}{c}31 \\
\pm 45\end{array}$ & $\begin{array}{c}30 \\
\pm 48\end{array}$ & $\begin{array}{c}178 \\
\pm 316\end{array}$ & $\begin{array}{c}30 \\
\pm 48\end{array}$ & $\begin{array}{c}9 \\
\pm 20\end{array}$ & $\begin{array}{c}0 \\
\pm 0\end{array}$ & $\begin{array}{c}60,123 \\
\pm 209,797\end{array}$ & $\begin{array}{c}66,732 \\
\pm 222,163\end{array}$ \\
\hline & Med. & 184 & 2,983 & 10 & 10 & 40 & 10 & 0 & 0 & 3,334 & 2,250 \\
\hline
\end{tabular}

Av. - average value; SD - standard deviation; Med. - median value; Ns - not studied 
Table 6. Number of WWTP (No.) and research stations (st.) in which the highest (hig.) and lowest (low.) median values (Med.) of the studied microorganisms $\left(\mathrm{CFU} / \mathrm{m}^{3}\right)$ occurred at different wastewater treatment stages and in background studies

\begin{tabular}{|c|c|c|c|c|c|c|}
\hline Microorganisms & Med. & $\begin{array}{l}\text { Mechanical } \\
\text { cleaning }\end{array}$ & Bioreactor & $\begin{array}{l}\text { Sludge manage- } \\
\text { ment }\end{array}$ & $\begin{array}{l}\text { Encapsulated } \\
\text { objects }\end{array}$ & $\begin{array}{l}\text { Background } \\
\text { research }\end{array}$ \\
\hline $\begin{array}{l}\text { Mesophilic } \\
\text { bacteria }\end{array}$ & $\begin{array}{l}\text { hig. } \\
\text { low. }\end{array}$ & $\begin{array}{c}3,590 \text { - No. } 8, \text { st. } 2 \\
60 \text { - No.1, st. } 4\end{array}$ & $\begin{array}{c}5,300-\text { No. } 5 \\
70-\text { No. } 1\end{array}$ & $\begin{array}{c}3,380-\text { No. } 5, \text { st. } 3 \\
117-\text { No.9, st. } 6\end{array}$ & $\begin{array}{c}4,940 \text { - No.7, st. } 1 \\
233 \text { - No.9, st. } 1\end{array}$ & $\begin{array}{c}205-\text { No. } 4 \\
40-\text { No. } 1\end{array}$ \\
\hline $\begin{array}{l}\text { Psychrophilic } \\
\text { bacteria }\end{array}$ & $\begin{array}{l}\text { hig. } \\
\text { low. }\end{array}$ & $\begin{array}{c}10,380-\text { No. } 3, \text { st. } 3 \\
260-\text { No.7, st. } 2\end{array}$ & $\begin{array}{c}8,150-\text { No. } 5 \\
580-\text { No. } 7\end{array}$ & $\begin{array}{c}\text { 7,200 - No. } 5, \text { st. } 3 \\
400 \text { - No.6, st. } 6\end{array}$ & $\begin{array}{l}5,934-\text { No. } 9, \text { st. } 1 \\
1,340 \text { - No. } 8, \text { st. } 1\end{array}$ & $\begin{array}{c}2,684-\text { No. } 9 \\
250-\text { No.6 }\end{array}$ \\
\hline $\begin{array}{l}\text { Staphylococcus } \\
\text { mannitolpositive }\end{array}$ & $\begin{array}{l}\text { hig. } \\
\text { low. }\end{array}$ & $\begin{array}{c}120-\text { No. } 2 \text {, st. } 1 \\
0-\text { No.1, st.4 }\end{array}$ & $\begin{array}{c}26-\text { No. } 2,4,6 \\
0-\text { No. } 1,3,8\end{array}$ & $\begin{array}{c}160-\text { No. } 2 \text {, st. } 6 \\
0-\text { No. } 5 \text {, st. } 3\end{array}$ & $\begin{array}{c}50-\text { No. } 7, \text { st. } 1 \\
0-\text { No. } 1 \text {, st. } 1\end{array}$ & $\begin{array}{c}26-\text { No. } 2 \\
0-\text { No.1, 3-9 }\end{array}$ \\
\hline $\begin{array}{l}\text { Staphylococcus } \\
\text { mannitolnegative }\end{array}$ & $\begin{array}{l}\text { hig. } \\
\text { low. }\end{array}$ & $\begin{array}{c}53-\text { No. } 2 \text {, st. } 1 \\
0-\text { No. } 1 \text {, st. } 4\end{array}$ & $\begin{array}{c}26-\text { No. } 5 \\
0-\text { No. } 1,3,4,7,8\end{array}$ & $\begin{array}{c}39-\text { No. } 4 \text {, st. } 5 \\
5-\text { No. } 7 \text {, st. } 8\end{array}$ & $\begin{array}{c}50-\text { No. } 8, \text { st. } 7 \\
0-\text { No. } 6 \text {, st. } 4\end{array}$ & $\begin{array}{c}10-\text { No. } 8 \text { and } 9 \\
0-\text { No.1-7 }\end{array}$ \\
\hline Actinobacteria & $\begin{array}{l}\text { hig. } \\
\text { low. }\end{array}$ & $\begin{array}{l}90-\text { No. } 7, \text { st. } 2 \\
30-\text { No. } 6 \text {, st. } 3\end{array}$ & $\begin{array}{c}85-\text { No. } 7 \\
0-\text { No. } 8\end{array}$ & $\begin{array}{l}150-\text { No. } 7 \text {, st. } 7 \\
55-\text { No.6, st.6 }\end{array}$ & $\begin{array}{c}230-\text { No.6, st. } 1 \\
20-\text { No.9, st. } 1\end{array}$ & $\begin{array}{c}560-\text { No. } 7 \\
10-\text { No. } 8\end{array}$ \\
\hline Coliform bacteria & $\begin{array}{l}\text { hig. } \\
\text { low. }\end{array}$ & $\begin{array}{c}40-\text { No. } 9, \text { st. } 2 \\
0-\text { No. } 1 \text {, st. } 2\end{array}$ & $\begin{array}{l}80-\text { No.5 } \\
0-\text { No. } 1,2\end{array}$ & $\begin{array}{c}53-\text { No.3, st.7 } \\
0-\text { No. } 7 \text {, st. } 7\end{array}$ & $\begin{array}{c}185-\text { No. } 8, \text { st. } 2 \\
5-\text { No. } 1 \text {, st. } 1\end{array}$ & $\begin{array}{c}10-\text { No. } 9 \\
0-\text { No. } 1-8\end{array}$ \\
\hline $\begin{array}{l}\text { Pseudomonas fluo- } \\
\text { rescens in } 26^{\circ} \mathrm{C}\end{array}$ & $\begin{array}{l}\text { hig. } \\
\text { low. }\end{array}$ & $\begin{array}{c}13-\text { No. } 2, \text { st. } 1 \\
0-\text { remaining }\end{array}$ & $\begin{array}{c}26-\text { No.5 } \\
0-\text { remaining }\end{array}$ & $0-$ All sites & $\begin{array}{c}40-\text { No. } 8, \text { st. } 2 \\
0-\text { No. } 8, \text { st. } 1\end{array}$ & 0 - No.1-9 \\
\hline $\begin{array}{l}\text { Microscopic fungi } \\
- \text { Waksman }\end{array}$ & $\begin{array}{l}\text { hig. } \\
\text { low. }\end{array}$ & $\begin{array}{c}6,800-\text { No.9, st. } 2 \\
950-\text { No.7, st. } 2\end{array}$ & $\begin{array}{c}6,350-\text { No. } 5 \\
590-\text { No. } 1\end{array}$ & $\begin{array}{l}8,850-\text { No.5, st. } 3 \\
1,320-\text { No. } 7, \text { st. } 7\end{array}$ & $\begin{array}{c}5,817-\text { No.9, st. } 1 \\
830-\text { No.8, st. } 1\end{array}$ & $\begin{array}{c}\text { 5,233-No.9 } \\
370-\text { No. } 1\end{array}$ \\
\hline $\begin{array}{l}\text { Microscopic fungi } \\
\text { - Czapek-Dox }\end{array}$ & $\begin{array}{l}\text { hig. } \\
\text { low. }\end{array}$ & $\begin{array}{c}8,650-\text { No. } 3, \text { st. } 3 \\
560-\text { No.7, st. } 2\end{array}$ & $\begin{array}{c}15,250-\text { No. } 5 \\
480-\text { No. } 7\end{array}$ & $\begin{array}{c}11,900-\text { No. } 5 \text {, st. } 3 \\
1,020-\text { No.6, st. } 6\end{array}$ & $\begin{array}{l}5,833 \text { - No. } 9, \text { st. } 1 \\
1,020-\text { No.8, st. } 1\end{array}$ & $\begin{array}{c}1,750-\text { No. } 9 \\
160-\text { No. } 1\end{array}$ \\
\hline
\end{tabular}

No. - number of WWTP

st. - number of the research station

In the case of some WWTPs, certain relationships were noticed between the abundance of detected microorganisms and the meteorological conditions. The air temperature ranged from -13.5 (winter) to $39.3^{\circ} \mathrm{C}$ (summer), and the average value from the complete measurement period was at $14.0 \pm 8.6^{\circ} \mathrm{C}$. The air temperature distribution is not a normal distribution ( $\mathrm{p}=0.0036$, Shapiro-Wilk test, assuming that the distribution is not normal when $\mathrm{p}<0.05$ ). In most cases (42.7\% of measurements) the temperature ranged from 10.0 to $20.0^{\circ} \mathrm{C}$ and then the highest abundance of bacteria and fungi was noted. The air humidity ranged from 24.0 to $99.8 \%$. The average humidity from all measurements reached $57.0 \pm 17.3 \%$. The distribution of air humidity is not a normal distribution ( $\mathrm{p}=0.0011$ Shapiro-Wilk test). The distribution is unimodal - in most cases the air humidity ranged from 50.0 to $60.0 \%$ (23.1\% of all measurements). The higher humidity favoured the occurrence of a higher abundance of microorganisms. However, in the many sampling points there was no significant relationship between concentrations of airborne bacteria as well as microscopic fungi and meteorological parameters. Similar relationships were observed by Fathi et al. [20] and Kermani et al. [24]. The wind speed ranged from 0.0 to $5.3 \mathrm{~m} / \mathrm{s}$. The average wind speed was at $1.4 \pm 1.0 \mathrm{~m} / \mathrm{s}$. The wind speed distribution is not a normal distribution ( $p=0.0000$, Shapiro-Wilk test). In most cases the wind speed reached from 0.0 to $1.0 \mathrm{~m} / \mathrm{s}(43.6 \%$ of all measurements). The above-mentioned microclimatic parameters are similar to numerous literature reports [3, 20, 21, 24-27].
The results of bioaerosol studies $\left(\mathrm{CFU} / \mathrm{m}^{3}\right)$ from the complete study period in all research stations (without the background studies - control stations) of specific WWTPs (No. 1-9; see Tables 3 and 4) were shown in a different form in Table 5. This table presents the average value (Av.), standard deviation (SD), and median value (Med.) for the studied microorganisms.

In contrast, Table 6 presents the highest and lowest median value of the studied microorganisms at the stage of mechanical treatment of wastewater, biological treatment (bioreactor), sludge management, encapsulated objects with respect to the WWTP number and research station number (No., st.), and background studies in the analysed WWTPs (No.).

Analysis of bioaerosol results obtained on the sites of 9 WWTPs allows for establishing the following:

- The microscopic fungi were the most abundant group among microorganisms present in the bioaerosol. The comparison of abundance median values of fungi during four seasons (the Kruskal-Wallis test) showed statistically significant differences ( $p=0.0000$ ) between them. The value $p<0.05$ was assumed as a statistically significant difference. The highest abundance of fungi during single studies was observed for WWTP No. 9. The highest contamination of air with microscopic fungi mostly occurred in the vicinity of bioreactor aeration chambers, at sludge collection sites, and during the stages of mechanical treatment of wastewater.

- Psychrophiles were the most abundant group of bacteria. Comparison of abundance median values of psychrophilic bacteria throughout the annum showed 
statistically important differences $(p=0.0000)$. The highest abundance of psychrophilic bacteria was observed during mechanical and biological treatment, at sludge collection sites, and in encapsulated (hermetic) screen buildings.

- Mesophiles were the second most abundant group of bacteria. Comparison of abundance median values of these bacteria in 9 areas throughout the annum revealed statistically significant differences $(\mathrm{p}=0.0083)$. The bioreactor aeration chambers, mechanical treatments stages, and sludge collection areas were the sites with the highest abundance of these bacteria.

- Coliform bacteria were the next most abundant group. The comparison of median values of the abundance of these bacteria in nine WWTPs throughout the annum revealed statistically important differences $(p=0.0002)$ between them. These bacteria were most abundant during mechanical treatment and near the bioreactors, while their abundance was lower at sludge collection sites.

- Actinomycetes (actinobacteria) were studied only in case of four WWTPs (Nos. 6-9). The comparison of abundance median values for actinomycetes during four seasons and on the studied WWTP areas revealed statistically significant differences $(\mathrm{p}=0.0000)$. These bacteria were most abundant during mechanical treatment and at sludge collection sites.

- Pseudomonas fluorescens bacteria incubated at $26^{\circ} \mathrm{C}$ were more abundant compared to those incubated at $4^{\circ} \mathrm{C}$. The comparison of abundance median values for pseudomonas fluorescens incubated at $26^{\circ} \mathrm{C}$ during different seasons did not reveal statistically significant differences $(\mathrm{p}=0.7393)$. Pseudomonas fluorescens bacteria incubated at $4^{\circ} \mathrm{C}$ were among the least abundant bacteria. Since these bacteria were present only during three measurements, no statistical analyses were conducted for this group.

- Mannitol-positive staphylococci $(\mathrm{m}+)$ were more abundant compared to the mannitol-negative group (m-). The comparison of median values of the abundance of these bacteria during the four seasons did not reveal any statistically significant differences $(\mathrm{p}=0.4284)$. This group was most abundant at sludge collection sites and during mechanical treatment.

- Mannitol-negative staphylococci (m-) were less prevalent compared to mannitol-positive $(\mathrm{m}+)$. Based on the results of the Kruskal-Wallis test, the comparison of abundance median values for this bacteria during four seasons did not reveal any statistically significant differences $(\mathrm{p}=0.8482)$. These bacteria exhibited the highest abundance during mechanical treatment and sludge management stages.

According to Vítězová et al. [27], the most abundant group of microorganisms in the monitored air were psychrophilic and mesophilic bacteria as well as microscopic fungi. The number of psychrophilic bacteria ranged from 14 to $12,000 \mathrm{CFU} / \mathrm{m}^{3}$, the number of mesophilic bacteria varied in the range from 20 to 18,500 $\mathrm{CFU} / \mathrm{m}^{3}$, and the fungi from 25 to $32,000 \mathrm{CFU} / \mathrm{m}^{3}$ in the air. However, as indicated by Azewedo et al. [23], the concentration of fungi in air was the highest in all locations of the treatment station. Similar relationships were noted in my studies, in which the dominant groups were microscopic fungi and psychrophilic, mesophilic, and coliform bacteria. Although psychrophilic and coliform bacteria are not specified in Polish Standards, their presence is a good indication of air contamination. Acording to Kruczalak and Olańczuk-Neyman [19], the sampling method affects the results of measurements of the number of microorganisms in the air. The numbers of microorganisms measured by means of impaction methods were 14 times lower on average than in the case of the sedimentation method. In the impaction method the volume of filtered air is strictly controlled, resulting in a more accurate measurement of the number of bacteria in the open air.

Some studies have suggested that the air becomes notably contaminated during the initial mechanical treatment of wastewater and includes viruses, faecal bacteria, and pathogens $[3,6,9,26,28]$. In my studies it was established that at these stages mesophilic, psychrophilic, and coliform bacteria as well as microscopic fungi are very abundant. It can be assumed that the pathogenic forms are also there. However, the microbial flora of the air is transitory and variable, since the quantity and types of contaminants are determined by existing sources of contamination in the environment [23]. Some WTPs produce higher concentrations of bioaerosols compared to others. The concentration of microorganisms in the air in a wastewater treatment plant is variable; there is a gradual decrease in bioaerosol emissions when the treatment process proceeds to further stages of purification. Szyłak-Szydłowski et al. [25] report that the highest concentrations of airborne bacteria were observed in the grit chamber and sludge storage site. At the same time, mesophilic bacteria were the most abundant group in the bioaerosol and other groups of bacteria were present at much lower concentrations. Partially similar relationships were noted in the WWTPs I studied. Other authors have reported that the biological stages of wastewater treatment (bioreactors) or sludge management areas are the main sources of bioaerosols. The aeration tank is considered a critical point due to the movement of the liquid. Fathi et al. [20] report that the processes of wastewater treatment, especially those using mechanical equipment to create turbulence, can be considered as a major source of spreading airborne microorganisms to the air surrounding wastewater treatment plants. Therefore, in order to decrease bioaerosol emissions, some actions, such as covering the surface of aeration basins and changing aeration methods and equipment (e.g., using a diffuser aerator), may be effective. Similar actions are used in the WWTPs I analysed. Niazi et al. [29] suggest 
that the main source of bioaerosol emissions in WWTPs are aeration chambers that contaminated the air with bacteria, as well as the initial stages of wastewater treatment and sludge treatment, which were associated with the highest emission of fungi. Similar trends were observed in WWTPs in Wielkopolska, in which the mechanical treatment stage, sludge management sites, and bioreactors were the most notable sources of emission of bioaerosols into the atmosphere. Similar data were reported by Kowalski et al. [30] during studies of several WWTPs in Poland, which indicated that the highest concentrations of bacteria in the bioaerosol occurred in sludge treatment sites and during mechanical treatment stages.

Additionally, Teixeira et al. [31] also reported that the highest microbial contamination of air may be noted during the initial treatment and sludge treatment. The authors note that apart from microorganisms, the gaseous contaminants should also be studied, since some of them may be dangerous and cause the presence of odours. Guo et al. [32] established that the ventilation of sealed rooms notably limits the emission of microorganisms into the environment. This specifically applies to the fine particles of bioaerosols, as bigger fractions settle down gravitationally at a faster rate. In the encapsulated objects present at the areas of the studied WWTPs, the contaminated air was discharged to biofilters, which notably limited the emission of microorganisms as well as odours to the atmosphere. The magnitude of this bioaerosol emission is influenced by factors such as WWTP capacity, applied treatment plant technology, applied treatment plant machines, applied treatment method, and content of contaminants in wastewater [21]. Numerous publications and my own studies have indicated that sewage treatment plants are a source of bioaerosol that may contain microorganisms (bacteria and microscopic fungi), posing a health hazard for both employees of these facilities and inhabitants of the surrounding areas. The risks of exposure can be reduced by locating sewage treatment plants outside urban centers.

\section{Conclusions}

- Evaluating the contamination rates of specific sites may be conducted based on the abundance of microorganisms $\left(\mathrm{CFU} / \mathrm{m}^{3}\right)$ or the $R_{a v}$ parameter, which represents the ratio of the average annual abundance of microorganisms in the contaminated air and the average annual microbial abundance in background studies (at the control site).

- The value of the $R_{a v}$ parameter at the site of nine studied WWTPs ranged from 0.5 (pure air) to 241.1 (very contaminated air - very high increase of contamination) and was diverse at times.

- The emission of bioaerosols to the atmosphere was observed during every stage of wastewater treatment.

- The mechanical treatment stages of wastewater, sludge management sites, and bioreactors were most notable sources of microorganisms.

- Although high microbial contamination of air was also noted inside sealed objects, encapsulation (hermetic) prevented the transfer of the bioaerosol into the external environment.

- Microscopic fungi as well as psychrophilic and mesophilic bacteria were the most abundant microbial groups in the bioaerosol.

- The presence of coliform bacteria reflects the level of air pollution with bioaerosols from sewage and is an important factor for monitoring the quality of the air around WWTPs.

- A wastewater treatment plant (WTP), due to its working conditions, is considered a major source of aerosols and may constitute an important health risk for plant workers as well as the surrounding residents.

\section{Abbreviations}

WWTPs - wastewater treatment plants

$\mathrm{CFU} / \mathrm{m}^{3}$ - colony forming unit per $1 \mathrm{~m}^{3}$ of air

$\mathrm{SD}$ - standard deviation

$(\mathrm{M}+)$ - mannitol-positive staphylococci

(M-) - mannitol-negative staphylococci

No. - number of WWTPs

st. - research station number

Av. - average

Med. - median value

\section{Conflict of Interest}

The author declares no conflict of interest.

\section{References}

1. KULIG A. Impact of municipal facilities on the environment and their evaluation. Problemy Ocen Środowiskowych, 1 (4), 43, 1999.

2. CARDUCCI A., TOZZI E., RUBUlOTTA E., CASINI B., CANTIANI L., ROVINI E., MUSCILLO M., PACINI R. Assessing airborne biological hazard from urban wastewater treatment. Water Res., 34 (4), 1173, 2000.

3. FILIPKOWSKA Z., JANCZUKOWICZ W., KRZEMIENIEWSKI M, PESTA J. Microbiological air pollution of the surrounding of Waste Water Treatment Plant with activated-sludge aerated by horizontal rotors. Pol. J. Environ. Stud., 9 (4), 273, 2000.

4. THORN J., BEIJER L., JONSSON T., RYLANDER R. Measurement strategies for the determination of airborne bacterial endotoxin in sewage treatment plants. Ann. Occup. Hyg., 46 (6), 549, 2002.

5. GÓRNY R.L. Biological aerosols - a role of hygienic standards in the protection of environment and health. Med. Srod., 13 (1), 41, 2010.

6. YE L., ZHANG T. Pathogenic bacteria in sewage treatment plants as revealed by 454 pyrosequencing. Environ. Sci. Technol., 45 (17), 7173, 2011. 
7. KORZENIEWSKA E. Emission of bacteria and fungi in the air from wastewater treatment plants - a review. Front. Biosci. (Schol. Ed.), 3, 393, 2011.

8. KOŁWZAN B., JADCZYK P., PASTERNAK G., GŁUSZCZAK J., PAWLIK M., KRAWCZYŃSKA M., KLEIN J., RYBAK J. Assessing Air Quality in the Proximity of a Municipal Sewage Treatment Plant: A Case Study. Ochr. Sr., 34 (2), 9, 2012.

9. MICHALAK A., PAWLAS K. Influence of biological aerosol from wastewater treatment plants on workers and the local residents health - literature review. Med. Srod., 15 (4), 116, 2012.

10. DUQUENNE P., MARCHAND G., DUCHAINE C. Measurement of endotoxins in bioaerosols at workplace: A critical review of literature and a standardization issue. Ann. Occup. Hyg., 57 (2), 137, 2012.

11. FORESTIER D., LECORNET É., MOSQUERON L., LAMBOLEZ L. Exposure to bioaerosols for wastewater treatment plant workers: Prioritization of the areas and tasks involving the greatest exposure, and prevention. Environ. Risque. Sante, 11 (2), 137, 2012.

12. SIALVE B., GALES A., HAMELIN J., WERY N., STEYER J.P. Bioaerosol emission from open microalgal processes and their potential environmental impacts: what can be learned from natural and antropogenic aquatic anvironments? Curr. Opin. Biotechnol., 33, 279, 2015.

13. ADAMUS-BIAŁEK W., WAWSZCZAK M., ŚWIERCZ A. Impact of sewage treatment plant on local environment. Proceedings of ECOpole, 9 (2), 397, 2015.

14. BAWIEC A., PAWĘSKA K., JARZĄB A. Changes in the microbial composition of municipal wastewater treated in biological processes. J. Ecol. Eng., 17 (3), 41, 2016.

15. TOMASI C., LUPI A. Primary and secondary sources of atmospheric aerosol. Atmospheric aerosols: Life cycles and effects an air quality and climate, First Edition. Edited by Tomasi C., Fuzzi S., Kokhanovsky A., Wiley-VCH Verlag GmbH \& Co. KGaA, 2017.

16. Polish Standards PN-89/Z-04111/02, Air purity protection. Microbiological testig. Determination number of the bacteria in the atmospheric air (emission) with sampling by aspiration and sedimentation methods, National Standards Body in Poland, Warsaw, 1989.

17. Polish Standards PN-89/Z-04111/03, Air purity protection. Microbiological testig. Determination number of the fungi in the atmospheric air (emission) with sampling by aspiration and sedimentation methods, National Standards Body in Poland, Warsaw, 1989.

18. KULIG A. Measurement-calculation methods in the environmental impact assessments of the municipal infrastructure, Warsaw University of Technology, Warsaw, 2004 [In Polish].

19. KRUCZALAK K., OLAŃCZUK-NEYMAN K. Microorganisms in the air over wastewater treamtment plants. Pol J Environ Stud., 13 (5), 537, 2004.

20. FATHI S., HAJIZADEH Y., NIKAEEN M., GORBANI M. Assessment of microbial aerosol emissions in an urban wastewater treatment plant operated with activated sludge process. Aerobiologia, 33, 507, 2017.
21. KRISTANTO G.A., ROSANA F.N. Analysis of Microbial Air Quality in the Surrounding Hospital's Wastewater Treatment Plants in Jakarta, Indonesia. MATEC Web of Conferences, 138, 08004, 2017.

22. LI Y., YANG L., MENG Q., QIU X., FENG Y. Emission characteristics of microbial aerosols in a municipal sewage treatment plant in Xi'an, China. AAQR, 13, 343, 2013.

23. AZEVEDO M.L.R.S., COUTO M.A.P.G., LEITE S.G.F., AZEVEDO B.R.S., ALMEIDA P.A., PROCÓPIO A.S., SILVA S.A. Evaluation of air samplers systems in the monitoring of bioaerosols at wastewater treatment plants. IJENS, 14 (3), 48, 2014.

24. KERMANI M., DEHGHANI A., FARZADKIA M., ASL F.B., ZEINALZADEH D. Assessment of bioaerosol contamination in an urban wastewater treatment plant in Tehran, Iran. Journal of Air Pollution and Health, 1 (3), 161, 2016.

25. SZYŁAK-SZYDŁOWSKI M., KULIG A., MIAŚKIEWICZ-PĘSKA E. Seasonal changes in the concentrations of airborne bacteria emitted from a large wastewater treatment plant. Int Biodeter Biodegr, 115, 11, 2016.

26. GOTKOWSKA-PŁACHTA A., FILIPKOWSKA Z., KORZENIEWSKA E., JANCZUKOWICZ W., DIXON B., GOŁAŚ I., SZWALGIN D. Airborne Microorganisms Emitted from Wastewater Treatment Plant Treating Domestic Wastewater and Meat Processing Industry Wastes. Clean Soil Air Water, 41 (5), 429, 2013.

27. VÍTĚZOVÁ M., VITEZ T., MLEJNAKOVÁ H., LOŠÁK T. Microbial contamination of the air at the wastewater treatment plant. Acta Univ. Agric. Silvic. Mendelianae Brun., 60 (3), 233, 2012.

28. HEINONEN-TANSKI H., REPONEN T., KOIVUNEN $\mathrm{J}$. Airborne enteric coliphages and bacteria in sewage treatment plants. Water Res., 43 (9), 2558, 2009.

29. NIAZI S., HASSANVAND M.S., MAHVI A.H., NABIZADEH R., ALIMOHAMMADI M., NABAVI S., FARIDI S., DEHGHANI A., HOSEINI M., MORADIJOO M., MOKAMEL A., KASHANI H., YARALI N., YUNESIAN M. Assessment of bioaerosol contamination (bacteria and fungi) in the largest urban wastewater treatment plant in the Middle East. Environ. Sci. Pollut. Res., 22 (20), 16014, 2015.

30. KOWALSKI M., WOLANY J., PASTUSZKA J.S., PŁAZA G., WLAZŁO A., ULFIG K., MALINA A. Characteristics of airborne bacteria and fungi in some Polish wastewater treatment plants. Int. J. Environ. Sci. Technol., 14, 2181, 2017.

31. TEIXEIRA J.V., MIRANDA S., MONTEIRO R.A.R., LOPES F.V.S., MADUREIRA J., SILVA G.V., PESTANA N., PINTO E., VILAR V.J., BOAVENTURA R.A. Assessment of indoor airborne contamination in a wastewater treatment plant. Environ. Monit. Assess., 185 (1), 59, 2013.

32. GUO X., WU P., DING W., ZHANG W., LI L. Reduction and characterization of bioaerosols in a wastewater treatment station via ventilation. J. Environ. Sci., 26, 1575, 2014. 
